\title{
Education in family medicine at the University of Mostar School of Medicine
}

\author{
Edita Černi Obrdalj, Snježana Curić, Amra Zalihić, Mirjana Rumboldt \\ Department of Family Medicine \\ School of Medicine, University of Mostar \\ Corresponding author: \\ Edita Černi Obrdalj \\ Zrinskih Frankopana 20 \\ 88000 Mostar \\ Bosnia and Herzegovina \\ ecerniobrdalj@gmail.com \\ Tel.: + 38736343220 \\ Fax: + 38736335600 \\ Received: 12 December 2011 \\ Accepted: 6 February 2012 \\ Copyright (C) 2012 by \\ Academy of Sciences and Arts

\begin{abstract}
Department of Family medicine has been formed in academic year cine University of Mostar. The formal members of department are professor and assistants who lecture and lead seminars. In addition, physicians in rural practices contribute to teaching of family medicine. Clinical teaching of family medicine at Mostar School of Medicine is organized in the summer semester of sixth year of the study. It lasts six weeks and contains lectures, seminars and practices. Every student has right and obligation to evaluate educational process at the end of the course in a form of questionnaire and essay. Family medicine continuously receives high marks by students, especially practices. Evaluation of teaching by students is good way of giving feedback about teaching. We believe that student opinion can revise and improve teaching practice. Our good experience and good marks may prompt the changing our educational curriculum to include family medicine at each study year of medical program.
\end{abstract} \\ 2002/2003, few years later after the foundation of the School of Medi-
}

of Bosnia and Herzegovina.

E-mail for permission to publish:

amabih@anubih.ba
Key words: Family medicine, Mostar, Education.

\section{Introduction}

School of Medicine at University of Mostar has been established in 1997 as the „youngest child" of University of Mostar. About 40 students are admitted each year (1). The study lasts six years, like in the most European countries (2). Due to lack of teaching staff, in the first years of work external and foreign professors participated in the teaching, mostly from Croatia, but also from Germany and Canada. At present the specificity of Mostar School is young teaching staff who has graduated there and cooperation with medical schools in Croatia (1).
Department of Family medicine has been formed few years later after the foundation of the school, at the beginning of sixth year of the study. The first head of Department was Dr Geoffrey Hodgetts from Queen's University of Kingston (Canada) who spent 10 years in Bosnia and Herzegovina during the "Balkan primary health care project" $(3,4)$. From 2007 to 2011 Department was led by Dr Mirjana Rumboldt from School of Medicine University of Split (5). Both of them supported the academic progress of local teachers and left their mark in functioning of the modern department. 
At the Department of Family Medicine professor lecture, while assistants lead seminars (1). All department members also have practices in family medicine settings. There are several practices in the Health center Mostar which belong to the Teaching center of School of Medicine University of Mostar.

In addition to the formal members of the department, six physicians in rural practices contribute to teaching of family medicine. Some of them are located more than 50 kilometers from the nearest hospital. These mentors are specialists of family medicine with at least five years of work in practice. They are well educated in teaching and mentoring. They all have certificates of at least one of the courses organized for mentors in family medicine such as Course for educators organized by School's staff, some of European Academy of Family Physician (EURACT) courses (Leonardo, Assessment, Bled and Dubrovnik course) and Teaching Improvement Project System in organization of Queen's University of Kingston (2, 6, 7). Every of the listed courses lasts at least 12 hours and guarantees basic knowledge in teaching, mentor-student communication and evaluation.

\section{The family medicine curriculum}

Clinical teaching of family medicine at Mostar School of Medicine is organized in the summer semester of sixth year of the study. It lasts six weeks, or 180 hours. The seminars and lectures have 60 hours, while the remaining of 120 hours students spend in the practice setting. Lectures and seminars contain the most common topics in family medicine and some topics which are not covered in other subjects, like communication skills, family violence, communicating bad news and talking with patients about sexual dysfunction. Lectures are interactive with a number of cases from the practice of family medicine. Seminars are lead by assis- tant professors. Students prepare cases from the practice of family medicine and present them to other colleagues.

Practical training lasts four weeks and takes place in practice of family medicine in the City of Mostar and remote rural practices. One mentor works with maximally three students and each student works in rural and urban practice.

In the first week of practical training, student meets team members who introduce her or him to the organization of teamwork and medical documentation. In this period of practical work, student observes the work of the mentor, trains to fill in various medical forms, prescriptions and referrals, and makes home visits with mentor or nurse. In the second and third week of the practice, the student performs parts of the clinical examination, simple diagnostic and therapeutic procedures such as ECG, flushing the ear, and taking blood samples. At the last week, student carries out a full clinical consultation under the supervision of the mentor.

Each group of students spends two days of training in Educational center of Health center Mostar, where they practice on the models. The students have opportunity to train different clinical skills such as ear, gynecological, prostate and breast examination, administration of intravenous injections and simple wound management and suturing.

\section{Evaluation of the curriculum}

Students have the right and obligation to evaluate the subject and teachers at the end of the course. They complete the questionnaire which has been designed at the School's level. Evaluation has been performed after the education block and before the exam. The rating of teachers includes the accuracy, interest, linking practical and theoretical knowledge, encouraging discussion, proper attitude towards the students and 
Table 1 Evaluation of educational process of family medicine at School of Medicine University of Mostar by students

\begin{tabular}{|c|c|c|c|c|}
\hline \multirow{2}{*}{ Form of teaching } & \multicolumn{4}{|c|}{ Students' average marks in academic years (mean \pm SD) } \\
\hline & $2007 / 08$ & $2008 / 09$ & $2009 / 10$ & $2010 / 11$ \\
\hline Lectures & $3.71 \pm 1.27$ & $4.92 \pm 0.28$ & $4.62 \pm 0.56$ & $4.49 \pm 0.75$ \\
\hline Seminars & $3.71 \pm 1.27$ & $4.77 \pm 0.44$ & $4.72 \pm 0.45$ & $4.27 \pm 0.96$ \\
\hline Practices & $4.13 \pm 0.87$ & $5.00 \pm 0.00$ & $4.72 \pm 0.45$ & $4.45 \pm 0.71$ \\
\hline Subject in general & $3.62 \pm 1.21$ & $4.82 \pm 0.80$ & $4.79 \pm 0.50$ & $4.38 \pm 0.87$ \\
\hline
\end{tabular}

teacher ratings in general, while the score of the subject includes evaluation of lectures, seminars, practice and subject in general (1).

Table 1 shows the evaluation process of family medicine at School of Medicine University of Mostar marked by students. Through years 2007 to 2011 the students highly evaluated the course, with practical work scoring the highest marks. The students evaluate lectures, seminars, practical training and subject in general. Evaluation is marked as: $1=$ bad, $2=$ sufficient, $3=$ good, $4=$ very good, $5=$ excellent.

Students also have an opportunity to evaluate the course in the form of an essay. They express their opinions and suggestions of the teaching process. Most objections concern the literature because of the lack of suitable textbook. Therefore, publishing a textbook is the priority of Department. Students mostly praise practical training, where they for the first time independently carry out the real patient under the supervision of mentor. Here is one of students' remarks as citation:" It was one of the best organized clinical subjects. I think that family medicine is the first subject where we have done clinical practice and have solved clinical problems in real clinical setting by ourselves. Finally, I have understood important role of family medicine in primary health care system. The best price goes to the mentors in a rural practice. I have only one negative remark - readings. We really need good textbook in family medicine."

It is known that an ineffective clinical teacher has a negative attitude toward residents, is inaccessible, and lacks skills in providing feedback, while the effective clinical teacher has skills in two-way communication, creates an educational environment that facilitates learning, and provides constructive feedback to residents (7). We believe that student opinions can revise and improve teaching practice and that continuing education of educators, especially for educators in general practice setting, is a good way to improve teaching techniques of mentors $(8,9)$.

Numerous studies indicate that general practice is well placed to become a major setting for medical student education (10, 11). Evidence for the positive role of general practitioners and general practice in medical education is growing, including the benefits of prevocational training in general practice $(12,13)$.

Our good experience and good marks may prompt the changing our School's educational curriculum to include family medicine at each year of medical studies. Also, our experience can be a useful source of information for similar studies and teaching reforms elsewhere.

Acknowledgment: We kindly thanks to the members of Organisation committee of the Undergraduate course "Modern medical education in family medicine" organized at the School of Medicine University of Split in October 2011.

Authors' contributions: Conception and design: ECO; Drafting the article: SC and AZ; Revising it critically for important intelectual content: MR. 
Conflict of interest: The authors declare that they have no conflict of interest. This article was not sponsored by any external organisation.

\section{References}

1. About faculty [homepage on the internet]. Mostar: Medicine faculty Mostar c2006 (updated 2008 May 20; cited 2011 December 07). Available from: ahttp://www.mefmo.ba/index.php?option=com content\&view=article\&id=19\&Itemid $=27$

2. Specialist Training in General Practice/Family Medicine [homepage on the internet]. Ljubljana: Europeana Academy of Teachers in General Practice/Family Medicine; c2008 (updated 2011 June 15; cited 2012 January 03) Available from: http:// www.euract.eu/resources/specialist-training

3. Balcans Primary Health Care Policy Project [homepage on the internet]. Banja Luka, c2006 (updated 2007 September 11; cited 2011 December 07). Avaliable from: http://porodicnamedicina.com/site/index.php/Novosti/Projekat-planiranja-primarne-zdravstvene-zastite-na-Balkanu. html

4. Eastern Europe [homepage on the internet]. Canada: Canadian International Development Agency; c2009 (updated 2011 Juli 19; cited 2011 December 2011). Avaliable from: http://www.acdi-cida.gc.ca/acdi-cida/ACDI-CIDA.nsf/En/JOS116144226-R54.

5. Learning with heart [homepage on the internet]. Split: Medicine faculty Split; c 2009 (updated 2011
Jun 21; cited 2011 December 09). Available from: http://www.mefst.hr/default.aspx?id=1340

6. Bulc M, Svab I, Radic S, de Sousa JC, Yaphe J. Faculty development for teachers of family medicine in Europe: reflections on 16 years' experience with the international Bled course. Eur J Gen Pract. 2009; 15(2):69-73.

7. Vrcić-Keglević M, Jaksić Z. International course Training of teachers in general/family practice: 20 years of experience. Lijec Vjesn. 2002;124(2):36-9.

8. Gjerde CL, Coble RJ. Resident and faculty perceptions of effective clinical teaching in family practice. J Fam Pract. 1982;14:32-7.

9. McGee SR, Irby DM. Teaching in the outpatient clinic. Practical tips. J Gen Intern Med. 1997;12:34-40.

10. Schultz KW, Kirby J, Delva D, Godwin M, Verma S, Birtwhistle R, et al. Medical Students' and Residents' preferred site characteristics and preceptor behaviours for learning in the ambulatory setting: a cross-sectional survey. BMC Med Educ. 2004; 6:12.

11. Larsen K, Perkins D. Training doctors in general practices: a review of the literature. Aust J Rural Health 2006; 14: 173-77.

12. Thistlethwaite JE, Kidd MR, Hudson JN. General practice: a leading provider of medical student education in the 21st century? Med J Aust. 2007; 16:124-8.

13. Svab I, Petek-Ster M. Long-term evaluation of undergraduate family medicine curriculum in Slovenia. Srp Arh Celok Lek. 2008;136(5-6):274-9. 